\title{
Marine Spatial Planning - Prospects for the Arctic
}

\author{
Sigrid Eskeland Schütz ${ }^{\star}$ \\ University of Bergen, Norway
}

\begin{abstract}
Marine Spatial Planning (MSP) is defined as an integrated and comprehensive approach to ocean governance. Planning has the potential to ensure ecosystem and biodiversity conservation and establish rational use of marine space, combining activities relating to extraction industries, maritime transport, fisheries and related services and infrastructure. This article looks at what part transnational and national marine spatial planning can play in the Arctic. There is no international convention on marine spatial planning, and there are no requirements under international law that marine plans, as such, should be prescribed by law. MSP-regulation in different jurisdictions is diversified. It is difficult to claim that the international rights and obligations of a state under UNCLOS, CBD or regional instruments such as OSPAR, need to be fulfilled through the instrument of marine spatial planning. The comprehensive EU approach to marine planning is thus of particular interest. The EU members Denmark, Finland and Sweden do not have coastlines bordering the Arctic. EU has no direct influence over the regulation of marine spatial planning in Arctic marine areas through its relationship to Greenland or Norway, states with a close connection to the EU. The status of marine spatial planning in the European Arctic is thus dependent on the policies of Norway, Greenland and Russia. It is an open question whether spatial planning will be used for preventive and precautionary purposes in the Arctic, before the area is overwhelmed by marine activities and spatial conflicts.
\end{abstract}

Keywords: Maritime spatial planning; marine spatial planning; land use planning; international law; EU; European Arctic

Responsible Editor: Margherita Paola Poto.

Received: June 2017; Accepted: November 2017; Published: February 2018

\section{Introduction}

In the ocean governance context, marine spatial planning has been the subject of considerable interest during recent years and is a rapidly developing management

^Correspondence to: Sigrid Eskeland Schütz. Email: sigrid.schytz@uib.no

(C)2018 S. E. Schütz. This is an Open Access article distributed under the terms of the Creative Commons AttributionNonCommercial 4.0 International License (https://creativecommons.org/licenses/by-nc/4.0/), allowing third parties to share their work (copy, distribute, transmit) and to adapt it, under the condition that the authors are given credit, that the work is not used for commercial purposes, and that in the event of reuse or distribution, the terms of this license are made clear.

Citation: S. E. Schütz. 'Marine Spatial Planning - Prospects for the Arctic” Arctic Review on Law and Politics, Vol. 9, 2018, pp. 44-66. 
concept. ${ }^{1}$ Marine spatial planning was originally a tool for the environmental protection of marine areas only. ${ }^{2}$ It has been transformed into a process for minimising and avoiding conflicts of interest in ocean use, while also taking ecological values and benefits of human usage into consideration. ${ }^{3}$ Marine or Maritime Spatial Planning (MSP) is defined as an integrated and comprehensive approach to ocean governance that is used to reconcile conflicting interests in an ocean area. ${ }^{4}$ MSP can thus be seen as a tool for integrated ocean management, a comprehensive ecosystem-based management approach. ${ }^{5}$

The United Nations Educational, Scientific, and Cultural Organization (UNESCO) defines MSP as "a public process of analyzing and allocating the spatial and temporal distribution of human activities in marine areas to achieve ecological, economic, and social objectives that usually have been specified through a political process". ${ }^{6}$ Characteristics of marine spatial planning include concepts based on ecosystems and areas, and plans that are integrated, adaptive, strategic and participatory. The objective of an MSP can be a need for effective coordination of human activities and to achieve the overall aim of sustainable development. MSP also has the potential to establish rational use of marine space by multi-use and densification, combining activities relating to, for example, renewable energy, extraction industries, aquaculture, cultural heritage, maritime transport, fisheries and related services and infrastructure. Multi-use and densification have the potential to reduce the costs of offshore operations and decrease demand for ocean space, thereby ensuring ecosystem and biodiversity conservation and addressing other environmental concerns.

The Arctic is facing a number of serious challenges as well as opportunities, including pollution and the opening of waterways due to climate change. As human pressure in the Arctic region increases, it can be argued that there is a growing need to effectively manage the ocean space within the jurisdiction of the coastal states to the Arctic Ocean, that is Canada, Denmark (in relation to Greenland and the Faroe Islands), Norway, the Russian Federation and the United States (US). ${ }^{7}$ Marine spatial planning could also be used to achieve a form of 'transnational planning', like traffic lanes for ships along a contiguous coastline of several states, dredging to keep waterways navigable or gates for linear infrastructure like pipelines and data cables. Marine spatial planning typically takes place within the $200 \mathrm{~nm}$ Exclusive Economic Zones (EEZ). ${ }^{8}$ For the area beyond national jurisdiction (ABNJ, generally beyond the EEZ) in the high Arctic, the need for comprehensive spatial planning is, due to its remoteness, less evident, and will not be discussed further.

Marine spatial planning at the strategic level is performed by the public authorities and is thus costly and time-consuming to administer. Decisions on whether to perform planning are driven by the level of competing interests in the marine area, including areas where human use competes with nature conservation and biodiversity interests. As a consequence, marine planning is particularly in focus in heavily used areas, such as the Netherlands, an area with high and rapidly increasing 


\section{S. E. Schütz}

demand for marine space. The pressure on space requires an integrated and holistic management approach, and planning can prove to be both timely and cost-efficient. If the level of competing interests is lower, particular drivers of planning can be identified that justify a planning initiative. Such drivers might be specific, for example to facilitate wind farms, petroleum extraction or sand and gravel extraction, or they might be more open, for example value creation in marine sectors. ${ }^{9}$ Studies show that MSP in Europe often focuses on achieving specific important national sectoral objectives. ${ }^{10}$ Whether national or transnational planning in the Arctic is timely or cost-efficient, and what drivers justify planning in the region, is beyond the scope of this article.

In the following, I will discuss the prospects of using national and transnational MSP as a management tool in the Arctic. A key question is what the Arctic states are doing in relation to MSP as of today, see section 5, though limited to the European Arctic. A prerequisite for the analysis is a common understanding of what we reckon as part of the concept of MSP. As there is no international or Arctic-specific convention on marine spatial planning, prescriptive marine planning regulation in different jurisdictions is highly diversified, and customised to suit national politics and horizontal or sector laws in national legal systems. Stakeholders at both the national and international levels represent conflicting values and narratives, in a diversity of legal cultures. So far, as a primarily national instrument, neither marine planning nor transnational planning are fixed concepts in international theory, making it difficult to grasp its nature, purpose and scope. Due to the many conceptual and policy frameworks for MSP, ${ }^{11}$ I have chosen a pragmatic approach. I will start by discussing the concept of MSP by comparing such planning to the more developed concept of terrestrial planning, see section 2 .

After this framing of the concept of MSP, section 3 reviews requirements relating to MSP in general international law, outlining any minimum requirements Arctic states must fulfil. In the same section, I will look at possible specific material or procedural requirements as a result of treaties or, arguably, as inherent to the MSP instrument itself.

Treaties of particular interest from a European perspective are those constituting the European Union and any (minimum) requirements on national MSP-regulation deriving from these. The EU has a strong marine policy, and regulatory framework in which marine spatial planning now plays a part. In section 4, I discuss the EU approach to marine planning and the vital question of whether EU regulations, through the Union's relationship to Denmark/Greenland and Norway, apply to the European Marine Arctic. In section 5, I outline the status of marine planning in the Arctic, limited to the European/Asian side of the globe and the Arctic communities in Greenland, Russia and Norway.

Finally, in section 6, I will look at the prospects of using marine spatial planning as a management strategy for the Arctic. The Arctic is at the meeting point of common law and civil law systems, drawing a line between the US and Canada, on the 
one hand, and the other Arctic states on the other, with different sub-categories of civil law systems at play as well. Thus, it is difficult to envisage any kind of potential political consensus on cooperation on marine spatial planning or transboundary spatial planning in the Arctic, and how such instruments, or treaties, could play out in the different legal cultures.

\section{The concept of MSP - in comparison to land use (terrestrial) planning}

It has been claimed that marine spatial planning is not radically different from terrestrial spatial planning or land use planning, ${ }^{12}$ also named the land-based cousin of marine spatial planning. ${ }^{13}$ This leads us to an interesting question: How does marine spatial planning differ from land use planning? In terms of appearance, a municipal land use plan in Norway looks similar to a marine plan in the Netherlands, with different geographical zones marked and hatched on a map, reflecting different qualities of or uses of the areas.

The purpose of, or reasoning behind, planning has similarities both on land and at sea. It can be argued that, as an overall objective, the sustainable development of land and marine areas should take place in an economic, social and environmental context, in line with the principles set out by the World Commission on Environment and Development. ${ }^{14}$ Although the term 'development' suggests new activity, in the same way as UNESCO's talk of "spatial and temporal distribution of human activities", it should be noted that protection or non-use of areas can be just as important.

Both for land and sea, planning is necessary in order to ensure effective coordination of activities and to prevent and reconcile conflicts between different human activities. Not only the outcome of this process, but the way in which the open democratic process is carried out serves to promote these goals, thus making marine spatial planning "an essential process for sustainable decision-making". ${ }^{15}$ It can be argued that for both land and sea, sustainable development and the distribution of human activities should take place through knowledge-based processes that respect values of 'democratic legitimacy', here used as keywords for the values such open processes should promote, see section 3. The potential cumulative effects of human activities within a defined geographical space, and - in coastal zone planning - the cumulative effects of activities onshore and offshore, represent an important knowledge base.

In a land use context, the geographical borders of the planning area are typically based on administrative borders, which define the limits of the competency of the regional or local authorities. These borders could extend out into the sea, e.g. to the baselines, ${ }^{16}$ or to the territorial border. But it can be assumed that, as in the case of Norway, the further one goes out into the open sea, the more authority that rests with national authorities, which, as opposed to terrestrial planning, offers a unique opportunity to shape the marine planning area in accordance with natural ecological borders. Ecological or hydrological boundaries can also provide a foundation for 


\section{S. E. Schütz}

framing terrestrial plans, as in the case of water management under the EU Water Framework Directive, which is based on watersheds. ${ }^{17}$ That said, there are a range of different management instruments that can be used to promote a cross-border approach to land use planning. Thus, planning both onshore and offshore can ensure an ecosystem-based approach. ${ }^{18}$

Regardless of similarities, there is a fundamental difference between land and sea because of the object of the planning. Compared to the situation onshore, plans for water columns represent an extra dimension in marine area planning, but are similar to plans for land covered in water.

Relevant public and private stakeholders differ between land and sea. Moving from the coastline out into open sea, the most obvious difference is the absence of private landowners. Administrative authority also differs. In Norway, regionally elected councils (primarily county councils) have jurisdiction over land use up to one nautical mile seaward of the baselines. ${ }^{19}$ Outside these areas, the Norwegian state, by law, has the authority to manage activity or to protect areas from activity. Both onshore and offshore, spatial planning is a cross-sectoral instrument that can help to address questions of coordination between different administrative sectors or ministries facing planning challenges.

\section{Requirements in general international law, treaties and inherent in the concept of marine planning}

The preamble to the United Nations Convention on the Law of the Sea (UNCLOS), 1982, states that "the problems of ocean space are closely interrelated and need to be considered as a whole". ${ }^{20}$ Though UNCLOS is a framework for ocean governance, it does not prescribe how to carry out holistic management. The convention remains silent about marine spatial planning as a management process, ${ }^{21}$ and does not comprehensively address specific planning needs in national marine areas or $\mathrm{ABNJ} .{ }^{22}$ Marine spatial planning can be used to ensure compliance with impact assessments and other obligations and rights granted under UNCLOS and international instruments such as the Convention on Biological Diversity (CBD). ${ }^{23}$ Obligations related to pollution in regional instruments such as OSPAR for the North-East Atlantic, ${ }^{24}$ or requirements related to environmental quality norms under the Water Framework Directive or Marine Strategy Framework Directive, ${ }^{25}$ can also be fulfilled through marine spatial planning, depending on how the planning instrument is designed. It is difficult to require, however, that the international obligations of a state be fulfilled through the instrument of marine spatial planning. There are several management instruments that can promote an integrated and holistic approach, MSP being one of these.

Even though marine spatial planning is not a fixed concept in international theory, there are some requirements under general international law that are of relevance. ${ }^{26}$ There is no requirement, as of now, to undertake strategic environmental assessments 
under customary international law. The situation is different, however, when a marine plan concerns industry, extraction or other projects, and the project can give rise to a transboundary risk to the environment or the marine environment of other states. Several cases put before the International Court of Justice (ICJ) have concerned national obligations under international law in situations where a planned project is seen as having a potentially significant adverse impact in a transboundary context.

In the 1997 Gabčíkovo-Nagymaros case, which concerned a large barrage project on the Danube, the ICJ interpreted a treaty between the Czechoslovak Republic and Hungary ${ }^{27}$ The ICJ interpreted the specific treaty as "not static" and "open to adapt to emerging norms of international law", including new environmental norms. ${ }^{28}$ The Court stated that new norms and standards have been developed, requiring in the particular case that the parties "together should look afresh at the effects on the environment of the operation". ${ }^{29}$ The court continued its argumentation in the Pulp Mills case from 2010 concerning a dispute between Argentina and Uruguay about the construction of pulp mills on the Uruguay River:

It may now be considered a requirement under general international law to undertake an en-
vironmental impact assessment where there is a risk that the proposed industrial activity may
have a significant adverse impact in a transboundary context, in particular, on a shared resource.
Moreover, due diligence, and the duty of vigilance and prevention which it implies, would not
be considered to have been exercised, if a party planning works liable to affect the régime of the
river or the quality of its waters did not undertake an environmental impact assessment on the
potential effects of such works.

Environmental impact assessments are thus obligatory under general international law in cases where there is a transboundary risk to the environment, including the marine environment, to other states. This requires an ex ante evaluation of the risk of significant transboundary harm, and the impact assessment "must be conducted prior to the implementation of a project". ${ }^{31}$ In 2011, this obligation was interpreted in an advisory opinion of the International Tribunal of the Law of the Sea to also include activities with an impact on ABNJ:

\footnotetext{
Although aimed at the specific situation under discussion by the Court, the language used seems broad enough to cover activities in the Area even beyond the scope of the Regulations. The Court's reasoning in a transboundary context may also apply to activities with an impact on the environment in an area beyond the limits of national jurisdiction; and the Court's references to "shared resources" may also apply to resources that are the common heritage of mankind. ${ }^{32}$
}

In a more recent case, Costa Rica v. Nicaragua from December 2015, the ICJ concludes that Costa Rica did not comply with its obligation under general international law to carry out an environmental impact assessment concerning the construction of a road to ensure that the design and execution of the project would minimise the risk of significant transboundary harm.

International law thus has implications for how national states in the Arctic can design their legislation or practice their MSP policy: In a situation where a marine plan 


\section{S. E. Schütz}

is intended to plan for an industry project that can cause significant transboundary harm, there is a duty to carry out an environmental impact assessment. The aim of the assessment is to ensure that the design and execution of the project will minimise the risk of significant transboundary harm. A problem that arises is to decide under what circumstances a marine plan is meant to plan for an industry project. It is difficult to argue that it should be decisive whether national law designates a process a '(strategic) plan', 'licence', 'concession' or similar. In my opinion, in order to fulfil the purpose of an impact assessment and to conduct the assessment "prior to the implementation of a project", the relevant question is whether the marine plan de facto represents the authorisation process for the project; the 'go ahead' for the project. If this is the case, obligations under international law apply. International law does not prescribe how to organise the marine planning process versus the impact assessment process. As long as an environmental impact assessment is conducted prior to implementation of a project, it can either be carried out separate to the marine plan, or integrated into the marine spatial planning process.

What other requirements under general international law could be of relevance? Legal norms differ in the extent to which they are precise and binding, and the extent to which they grant leeway for interpretation. An interesting question is whether a marine plan under general international law, needs a foundation in formal law to be regarded as a marine spatial plan? And, regardless of its formal status, is it mandatory to create such a plan? Since marine planning is not regulated under international law, it is of interest to look at UNCLOS and the regulation of sea lanes and traffic separation schemes in the territorial sea in art. 22. Here, no requirements for a foundation in law exist. The text provides for "such sea lanes and traffic separation schemes as it may designate or prescribe for the regulation of the passage of ships" (no 1), and the coastal state "shall clearly indicate such sea lanes and traffic separation schemes on charts to which due publicity shall be given" (no 4). Equivalent requirements are prescribed for lanes in straits for international navigation under art. 41. Neither art. 192 on the duty to "protect and preserve the marine environment", nor art. 65 or 120 on the conservation and management of marine mammals, requires prescription by law. Sea lanes and restrictions on sailing in protected areas can be regarded as one of the most restrictive measures in relation to third parties under marine spatial planning. Since only requirements for 'due publicity' of such plans are highlighted under international law, it could be argued that there are no requirements under international law that marine plans, as such, should be prescribed by law. A conclusion that can be drawn, is that if a nation state's marine plan is identical to the chart designated for presenting sea lanes and traffic separation schemes to the public, the plan must be given due publicity.

If we look at how some Arctic states have used law as an instrument in MSP, Canada was the first country in the world to adopt comprehensive legislation for integrated ocean management by passing its 1997 Oceans Act, and it has since developed an 'Integrated Oceans Management Plan for the Beaufort Sea: 2009 and beyond'. ${ }^{33}$ 
The objective of the plan is to carry out large-scale spatial planning. The Act has been criticised, however, for having inadequate governmental arrangements for its implementation, and challenges stemming directly from the absence of specific provisions and/or regulations giving integrated management plans legal force. ${ }^{34} \mathrm{In}$ addition, there are no requirements for other federal departments to comply with or implement the Act. The United States is subdivided into nine regional planning areas under the National Ocean Policy, based roughly on large marine ecosystems (Alaska being one) ${ }^{35}$ Marine planning is not mandatory but a voluntary, regional process. In Norway, there is a clear political commitment to develop management plans for all Norwegian seas, but the marine management plans for the North Sea, Norwegian Sea and Barents Sea have no legal foundation. ${ }^{36}$ Because of the lack of prescriptive rules, such plans are primarily of an advisory nature, aimed in particular at guiding future public management of different marine sectors through more detailed, sector-specific management instruments, e.g. granting licences for or 'opening' areas for petroleum activity or windfarms. ${ }^{37}$

As discussed above, there are few requirements under international law on national marine spatial planning, besides those which can be actualised regarding impact assessment and giving due publicity to sea lanes and traffic separation schemes. This leads to the question of whether there are any material or procedural requirements deriving from treaties or inherent in the concept of marine spatial planning.

It is inherent in the concept that MSP is a process finalised by some sort of 'plan', and spatial planning indicates that it is not just planning of, for instance, social and economic development, but a plan that leads to mapping or zoning of geographical sea areas, the water column, seabed or subsoil. Mapping might indicate qualities of the area, such as important ecological areas, or possible future preferred use. Mapping can be either regulatory and enforceable or advisory. Its addressees can be public authorities, but also private stakeholders. As a spatial mapping exercise, visualisations are key. In the Norwegian management plans, texts are combined with illustrations on - among other things - maps, but, as of yet, there is no all-encompassing map summing up the different areas and zones illustrated in the document.

Under the umbrella of marine spatial planning, we can include the protection of marine areas along with traffic lanes and separation schemes. Spatial planning and the protection of marine areas can potentially be parallel and interlinked processes. Already protected marine areas can be considered as constraints in the planning process, and the planned use of such areas should not be in conflict with or undermine the purpose of these protected areas. Since marine spatial planning and marine protected area management are both immature and developing instruments, the formal link between the two can be weak or lacking.

The ocean surface conceals spatially heterogeneous patterns where the topography, water stratification and movement, living things, and human interests and impacts vary, and time scales can be in hours or centuries, requiring managers who understand and take account of the sea's heterogeneity in space and time. ${ }^{38}$ As stated in the 


\section{S. E. Schütz}

UNCLOS preamble, the problems of ocean space are closely interrelated and need to be considered as a whole, thus holistic management can be seen as part of the concept of MSP. The extent to which a marine plan, encompassing spatially heterogeneity, constitutes a holistic management instrument, depends partly, in my view, on 1) the spatial scale of the plan, 2) the marine governance system the plan is part of, and 3) the activity addressed. The question of scale discussed above, comparing land use planning and MSP, points to the possibility of shaping the marine planning area in accordance with natural ecological borders. Scaling also extends to transnational marine planning. Transnationality can encompass transnational boundaries of the management area, the sharing of information, joint administration, agreeing on joint rules, a joint organisation and so on.

A marine plan could be included as a part of a national marine governance system. Whether or not the plan is included in a hierarchy of marine spatial plans is closely related to the question of geographical scale. Experience has shown that traditional licensing procedures are inadequate in terms of evaluating realistic alternatives for future development and addressing cumulative impacts, and that " $[\mathrm{t}]$ he issue of alternatives can only be properly assessed at the plan and programme level". ${ }^{39}$ It has also been pointed out that it is inappropriate to assess cumulative or larger-scale impacts based on piecemeal project-based assessments. ${ }^{40}$ Thus, an important development in spatial management has been the adaptation of more strategic and holistic instruments for the management of areas and resources, compared to the traditional (sector) licensing system. Ideally, a vertical management hierarchy would link strategic planning to downstream project licences through all stages of development, contributing to a holistic approach.

The extent to which a marine plan constitutes a holistic management instrument further depends on the activity addressed. Is it sufficient that a plan should only encompass one marine sector, such as petroleum activity? The Canadian Oceans Act, for instance (part 2), calls for "the development of plans for the integrated management of all activities or measures in marine waters". The new paradigm of environmental management, the ecosystem-based management approach, ${ }^{41}$ supports the argument that the scale of the management objective should be large marine ecosystems and should encompass all major sectors. We find a more pragmatic approach in the understanding of the Conference of the Parties to the CBD, where it is argued that:

The [ecosystem] approach should be bounded by spatial and temporal scales that are appropriate to the objectives. Boundaries for management will be defined operationally by users, managers, scientists and indigenous and local peoples. Connectivity between areas should be promoted where necessary. The ecosystem approach is based upon the hierarchical nature of biological diversity characterised by the interaction and integration of genes, species and ecosystems. ${ }^{42}$

This statement underscores that the ecosystem/holistic approach does not give any clear directives. The questions of spatial scale and sectors encompassed by a plan 
cannot be considered in isolation from a particular marine governance structure, or the legal cultural context of the state in question. ${ }^{43}$ There is no single path to good ecosystem management. A state's particular marine governance structure is decisive for the design of marine spatial planning instruments in this respect, and spatial planning can cross ecosystem boundaries, socio-economic boundaries or jurisdictional boundaries.

When politicians or public authorities are in the process of adopting a marine spatial plan, determining outcomes regarding spatial use is difficult to frame on the basis of strict legal obligations; there will presumably be some leeway for interpretation, that is, it will allow for the weighing of pros and cons. Prescriptive marine spatial planning is thus generally of a procedural nature, i.e. it defines how to go about planning a marine area. In a striking parallel to the regulation of environmental impact assessments and strategic environmental assessments, procedural rules can "prohibit uninformed, but not unwise, decisions". ${ }^{44}$ As regards impact assessments, endeavours are being made to close the procedure vs. substance divide by coupling assessments with the design of protective measures. ${ }^{45}$

The planning procedure should ensure both a knowledge-based decision process (knowledge-based management) and an open and democratic planning process (democratic legitimacy). We can designate these procedural elements as intrinsic to western democracies due to these countries' obligations as signatories to the Aarhus Convention. ${ }^{46}$ The convention gives everyone a right to receive environmental information held by public authorities and a right to participate in environmental decision-making, and to comment on plans and programmes, or proposals for projects that affect the environment. For planning with transnational implications, there are also obligations under the Espoo Convention, ${ }^{47}$ as well as in the subsequent protocol on Strategic Environmental Assessment (SEA Protocol), ${ }^{48}$ both of which do not include ABNJ. The US and Russia are Arctic coastal states that are not parties to the Espoo Convention.

Procedural principles or rules on access to information and public participation have typically been developed under international conventions like the Aarhus Convention, but for environmental impact assessment at the strategic and the project level, they have also been included in the SEA- and EIA-directives, in an EU context. ${ }^{49}$ The Aarhus Convention and the EU Directives on Impact Assessment emphasise an open and public process that involves stakeholders in a transparent way. General principles of administrative law, like public participation, knowledge-based management, environmental impact assessments at both the strategic and the project level, access to information and other well-established principles, are part of both terrestrial and marine spatial planning.

The Arctic picture is not homogenous in this sense, since Russia, Canada and the US have refrained from signing the Aarhus Convention. The US and Canada have explained that their legal system already adequately provides for public participation. ${ }^{50}$ Russia participated in the negotiations and had several adjustments made to 


\section{S. E. Schütz}

the convention text, but refrained from signing in the end. ${ }^{51}$ Consequently, the Aarhus Convention cannot be used to make assumptions about procedural requirements in non-signatory countries like Russia. A comparative study of Finnish (Finland has signed the Aarhus Convention) and Russian land use planning concludes that public participation is obligatory at all planning levels in both countries, and that the systems are the same. ${ }^{52}$

\section{The EU approach. Does EU has a say in the European Marine Arctic?}

Two Arctic marine states - and Arctic Council members - have a close connection to the European Union, namely Norway through the EEA Agreement, and Greenland through its common foreign policy with Denmark, an EU member state. ${ }^{53}$ In this light, the EU approach to marine spatial planning is of particular interest when discussing the European Marine Arctic. What is the approach, and does EU have a say in the European Marine Arctic?

The idea of effective cross-border cooperation between member states of the European Union and cooperation with third countries was a driving force behind the establishment of the EU Framework Directive on Maritime Spatial Planning (MSP) (2014/89/EU). This directive also defines minimum requirements for marine/maritime spatial planning in the EU in the years to come.

The directive has established a framework for marine spatial planning. It is one of two essential tools under the EU's Integrated Maritime Policy along with the Marine Strategy Framework Directive (2008/56/EC), a directive which establishes a framework for European Community action in the field of marine environmental policy. The directive aimes at achieving 'good environmental status' (GES) in marine waters, which includes both ecological status (life in the sea) and chemical status (pollution).

Under the EU Framework Directive on MSP, 'Maritime spatial planning' means a process of analysing and organising human activities in marine areas to achieve ecological, economic and social objectives. ${ }^{54}$ Other requirements include the use of best available data and the involvement of stakeholders in the process. It was originally meant to encompass coastal zone planning, but the member states did not agree to include this in the final proposal.

As a legal instrument, the provisions in the directive are quite basic, which illustrates the difficulty of regulating administrative law in countries with diversified legal cultures and policies regarding the organisation of marine areas and resources. Under the directive, it is a requirement that each member state shall identify a competent authority. ${ }^{55} \mathrm{~A}$ clear requirement stating who is responsible can promote effective cross-border cooperation between member states and with neighbouring third countries. Further, each member state shall establish and implement maritime spatial planning. ${ }^{56}$ Maritime spatial plans shall be reviewed at least every ten years. ${ }^{57}$ It is clearly expressed in the preamble recital 11 and art. 4 section 3 that member 
states retain responsibility for and competence to design and determine, within their marine waters, the format and content of such plans, including institutional arrangements and, where applicable, any apportionment of maritime space to different activities and uses. It can be assumed that the new EU maritime spatial planning regime will expand and develop in the years to come, with adjusted and revised requirements in future revisions of the legislation.

Other directives are also of relevance to marine spatial planning in the European Union. Of particular interest are situations where marine plans are intended for industry, extraction or other projects likely to have significant environmental effects. The directive on the assessment of the effects of certain plans and programmes on the environment, the SEA Directive, applies to a wide range of public plans and programmes, e.g. for transport, fisheries, energy, industry, telecommunications, tourism and waste ${ }^{58}$ Under art. 3. 2 (a), a strategic impact assessment is mandatory for plans/ programmes likely to have significant environmental effects, in order to prepare for these sectors and "set the framework" for future consent for development projects listed in the directive on the assessment of the effects of certain public and private projects on the environment, the EIA Directive. ${ }^{59}$ The procedure for determining whether the plans/programmes are likely to have significant effects (screening) must be based on criteria set out in Annex II of the Directive. If an SEA is needed, the procedural requirements under the Directive must be met and are likely to impact the marine planning procedure.

After this brief introduction to MSP in the EU, it is important to remember that the three Arctic EU Member States - Denmark, Finland and Sweden - do not have coastlines bordering the Arctic. The EU acknowledges that the Union "has no Arctic Ocean coastline so far". ${ }^{60}$ The following question is whether the European Union has a say in the European Marine Arctic due to the relationship to the marine Arctic states Denmark/Greenland and Norway.

Denmark, an EU member, has a close historical connection to Greenland, which was a Danish colony until 1953. Today, Greenland is an autonomous country within the Kingdom of Denmark. Denmark still retains control of Greenland's foreign affairs and defence. ${ }^{61}$ The Government of Greenland has overall management responsibility and the right of self-determination over biodiversity and living resources.

Both Greenland and Denmark joined the EEC, which later became the EU, in 1973. However, in 1985, Greenland withdrew from the EEC. So, EU legislation on marine spatial planning does not apply directly to Greenland and its Arctic EEZ. Relations have continued to be strong between the EU, on the one hand, and Greenland and Denmark, on the other, most recently through a partnership agreement. ${ }^{62}$ The partnership agreement acknowledges the geostrategic position of Greenland in the Arctic region, and main areas of cooperation include natural resources, energy, climate, environment and biodiversity, see art. 3 Sections 3 and 4. Questions addressed in the Framework Directive on MSP and the Marine Strategy Framework Directive are included in the partnership agreement. ${ }^{63}$ 


\section{S. E. Schütz}

Norway is not a member of the EU, but belongs to the European Economic Area (EEA). ${ }^{64}$ The EEA Agreement does not apply to Svalbard, the archipelago located at $78^{\circ} \mathrm{N}$, even though Svalbard is under Norwegian jurisdiction. Norway is integrated in the EU's internal market, with the exception of its nature conservation and fisheries policies. Regarding the geographical scope of the EEA agreement, Norway has taken the position that it only applies on Norwegian "territory", ${ }^{65}$ which means that the agreement is not relevant to legislation primarily meant for areas outside the territorial border 12 nautical miles beyond the baseline. The Norwegian position on the EEA Agreement has led it to reject the relevance under the agreement of, among other things, the Framework Directive on MSP and the Marine Strategy Framework Directive. The EU has thus no direct influence over the regulation of MSP in Arctic marine areas through its relationship to Greenland or Norway. That said, EU and Denmark could influence environmental protection and MSP in Greenland through their partnership agreement. ${ }^{66}$

\section{Status of marine spatial planning in the European Arctic}

What is the current status of marine spatial planning in Arctic Europe? This question depends on what Norway, Greenland and Russia are doing as regards marine spatial planning.

In Norway, land use and planning of coastal waters are regulated by the 2008 Planning and Building Act (PBA) ${ }^{67}$ On land and in coastal waters up to one nautical mile out to sea, the elected municipal councils have, in principle, autonomy to decide land use, and whether an area should be designated for outdoor recreation purposes, industry, energy production etc. ${ }^{68}$ Stakeholders are typically municipalities and private owners of land, seabed or water columns subject to private property rights. The municipal master plan provides an overview of land use purposes, but applications for new projects are required to submit a zoning plan for major building and construction projects, outlining details of land use in the specific project. ${ }^{69}$ The plan must comprise a planning map and requirements and must, to the extent necessary, show the main objectives and areas requiring special consideration in relation to the use and conservation of land.$^{70}$ In relation to land use objectives, requirements may be stipulated to the extent necessary concerning, e.g., the use and protection of water surfaces, water columns and bottom, and traffic at sea, or the groups of species or aquaculture species that may be established separately or in combination. ${ }^{71}$ The municipal master plan and zoning plans have legal force and are binding on future land use. Thus, for marine spatial planning up to one nautical mile beyond the baseline, the marine planning instrument is a sophisticated tool that has been developed over time. These processes are also open for public and stakeholder participation.

The open sea, on the other hand, has no decentralised institutions for decisionmaking, no private owners, and no municipal or regional authorities. For these areas, Norway has developed integrated management plans. There are three planning 
regions: the North Sea, the Norwegian Sea, and, of relevance to the Arctic, the Barents Sea - Lofoten area. The Barents Sea plan covers areas beyond the baseline one nautical mile off the coast, and the fishery protection zone around the Svalbard archipelago. This work was initiated by a government white paper 'Protecting the Riches of the Sea', 2002. ${ }^{72}$ The integrated management plan for the Barents Sea was first established in $2006,{ }^{73}$ having been developed through a broad, multifaceted process involving a number of government ministries and directorates, coordinated by a steering committee with representatives from the authorities with responsibility for environmental protection, fisheries and coastal affairs, oil and energy, and foreign policy, chaired by the Ministry of the Environment. The overall goal of the integrated management plan is to safeguard marine ecosystems and to ensure safe and sustainable use of resources in the area. Such management plans are intended to be dynamic instruments; the plan was updated in $2011 .{ }^{74}$

In 2003, preparations were made for the scientific basis for the plan, then sectoral studies were conducted in 2004, covering offshore fishing, shipping, and petroleum activities (aquaculture and coastal zone development are not covered), before it was finalised through integrated studies of the overall pressures in 2005. Though the ecosystem approach is highlighted, it was a drive for increased oil production in the Barents Sea that led to work being initiated on the plan. ${ }^{75}$

The planning process for the Barents Sea consisted of the preparation of status reports and included the collection of all relevant information, such as mapping of vulnerable areas and fishing activity from fishing vessels larger than 21 metres. The plan aims to ensure sustainable use of the ecosystem within acceptable levels of pollution, a reduced risk of accidental spills and sufficient capacity to deal with accidents, and seafood that is safe for consumption, while maintaining biodiversity at all levels. More specifically, the plan calls for alternative shipping lanes outside territorial waters, to reduce the risk of collisions.

As marine management plans in Norway are policy documents, there is no legal obligation to develop such plans, and no legal requirements regarding procedure or impact assessment. No regulation states what the outcome of the plan means in a legal context. There is no final map encompassing all activity. The plan is a management plan, but it is difficult to claim it has the characteristics of a marine spatial plan. ${ }^{76}$ The policy document sets the framework for subsequent spatial use processes under sector legislation, such as the Petroleum Act, Offshore Energy Act or marine protected areas under the Marine Resources Act. ${ }^{77}$ These sector-based spatial planning processes build on knowledge from the management plan, and the opening of areas for the extraction of oil or production of energy, such as offshore windfarms, takes place through strategic impact assessments conducted as part of the opening process.

Marine spatial planning has a terrestrial analogy in Russia called 'territorial planning ${ }^{78}{ }^{7 n}$ the Russian Federation, land use planning is based on the Land Use Code (2001) and Town Planning Code (2004). ${ }^{79}$ The codes require that a uniform system 


\section{S. E. Schütz}

of territorial planning are developed in the Russian Federation. Specially protected natural areas are incorporated into the plans. Marine spatial planning is not a term that has been officially used in connection with marine areas in Russia, but 'functional zoning' exists, such as marine protected areas, shipping zones, areas of maritime ports, zone of the Navy Department, zones of underwater cables and pipelines, fishing zones, production areas, areas for exploration of minerals, tourism and recreation. ${ }^{80}$ Thus zoning is not limited to the creation of protected areas, but comprises a broad range of instruments, some of which are already present in Russian legislation. ${ }^{81}$ Marine spatial planning as a holistic, open process based on the ecosystem approach is still not in place in Russia, and marine spatial plans are not available as documents, since there is no normative legislative basis for them. There is no SEA legislation in Russia. ${ }^{82}$

Ocean waters in Russia are under the exclusive oversight of the federal authorities, but their management falls under a number of different ministries. ${ }^{83}$ In the same way as Norway faced huge challenges in developing sector cooperation and a shared understanding of the integrated management of the Barents Sea, Russia is encountering equally great challenges in its work on the development of a management plan for the Russian part of the Barents Sea. ${ }^{84}$ New federal laws need to be adopted for this purpose, and regional and local authorities need a deeper understanding of integrated environmental management. ${ }^{85}$

For the non-Arctic Baltic Sea, there is regional implementation of the ecosystem approach under the Helsinki Convention. ${ }^{86}$ Denmark, Estonia, Finland, Germany, Latvia, Lithuania, Poland, Russia and Sweden, as well as the EU, have adopted ecological and management objectives and an action plan for the Baltic Sea. ${ }^{87}$ The action plan, and the path taken to develop it, will hopefully serve as a useful example of the possibilities, but naturally also the potential pitfalls, of implementing the ecosystem approach in a regional transboundary setting. ${ }^{88}$ Even though the focus of the action plan is on ecology and pollution, it recommends that the contracting parties "jointly develop the marine and coastal broad-scale spatial planning common principles to facilitate the protection and sustainable use of the Baltic Sea". ${ }^{89}$ A Working Group has worked since 2010 for regionally coherent MSP processes in the Baltic Sea. ${ }^{90}$ This illustrates that Russia is participating in cooperation on transboundary ecosystem management and marine spatial planning.

Greenland has a small but dispersed population of 55984 people (1 Jan. 2015) divided between 75 inhabited areas. There are no roads between these individual communities, the inhabitants of which derive their livelihoods from traditional fishing and hunting. The country is dependent on financial support from Denmark. The average age of the population is increasing, the number of unemployed remains high, and many people are moving from outlying areas to larger towns. ${ }^{91}$ As of today, Greenland is not a petroleum producer, but several petroleum prospecting licences and exploration and exploitation licences have been granted. ${ }^{92}$ NUNAOIL A/S is Greenland's national oil company, owned by the Government of Greenland and an 
active partner in all exploration and exploitation licences in Greenland. ${ }^{93}$ The official policy of the Government of Greenland is political independence through economic independence from Denmark, and mineral and petroleum extraction is therefore given high priority. ${ }^{94}$

The land use planning regulations from 2010 have no clear delimitation in relation to the sea, and open for the planning of harbours and aquaculture. ${ }^{95}$ Some initiatives have been undertaken for the long-term sustainable management of Greenland's wildlife. The resources and manpower available are scarce in comparison to the vast geographical area to be covered. ${ }^{96}$ The development of management plans for protected areas is given very high priority. ${ }^{97}$ Such management initiatives only cover selected aspects of Greenland's natural resources, and not the broader Arctic. Though several initiatives have been taken for ecosystem-based management, no marine spatial plan is yet in place in Greenland..$^{98}$ In relation to petroleum and mineral licensing, the aim is to develop new and improved systems to handle spatial and geological data, and to increase the efficiency of processing applications. ${ }^{99}$

\section{Prospects for the Arctic}

Last, but not least, what are the prospects for the future as regards marine spatial planning in the Arctic?

The Arctic is facing increased pressure from climate change, but also from human activity and environmental hazards and contaminants. We expect increased human activity in the Arctic from transport, oil and gas extraction, mining (on land and deep sea), aquaculture, fisheries and urbanisation. In 2015, Norway completed its first pipeline that crosses the Arctic Circle, a $482 \mathrm{~km}$ long pipeline that crosses 27 existing pipelines and cables, opening a new highway for gas to Europe. ${ }^{100}$ The demand for better connections between Tokyo and London is a driving force behind a recent proposal to lay a fiber-optic cable through the Arctic, an engineering feat which was previously considered impossible. Such cables will provide high-speed connections to communities and industries along the Arctic coast, and is now under construction. ${ }^{101}$

For the high seas, it is argued that the "increasing pressures of high seas human activities, suggests a pressing need for overarching institutional arrangements to better coordinate comprehensive MSP". ${ }^{102}$ For ABNJ in the Arctic Ocean, the question of whether there is a need for protection of marine biodiversity has been raised. ${ }^{103}$ Environmental protection, tailored to create a network of MPAs located within the national jurisdiction of the Arctic States, is already in focus through the work of the Arctic Council. The Council has developed a guidance document, establishing a "Framework for a Pan-Arctic Network of Marine Protected Areas". ${ }^{104}$ For marine protection in the high seas, the UN General Assembly adopted in 2015 a resolution to develop a legally binding treaty for the conservation of marine biodiversity in $\mathrm{ABNJ} .{ }^{105} \mathrm{After}$ a two-year preparatory process to develop such a treaty, the UN will decide whether to convene a formal treaty negotiating conference. Conservation measures, such as 


\section{S. E. Schütz}

marine protected areas and reserves, could be a part of the treaty, as well as environmental impact assessments at the strategic and project levels prior to engaging in or authorising activities/plans that may have significant effects on the marine environment in ABNJ. Such a UN-treaty for marine protection in ABNJ is likely to impact the construction of national marine policies, even within national jurisdictions and policy areas outside marine protection, like MSP.

The increasing pressure for both development and protection in the Arctic Ocean is leading legal scholars, politicians and planners to carefully examine management concepts from other marine regions. Some argue that prescriptive regulations were contributory factors to the Deepwater Horizon accident, because they made the industry unnecessarily passive while waiting for government controls. ${ }^{106}$ It has been argued that goal-based regulations to control safety and environmental pollution are a preferable solution. This approach, which would also include defining the goals, is best implemented within a spatial planning framework. ${ }^{107}$

The discussion about using management tools like ecosystem-based management, environmental impact assessments at the strategic and project levels, marine spatial planning and marine protected areas is inevitably 'moving northwards'. Still, planning activity in marine ecosystems is time consuming and requires high-level competencies. As a public task at the strategic level it is costly for states or regions. Whether marine spatial planning is suitable in the Arctic is therefore an open question. The guidance document on marine spatial planning from the intergovernmental Oceanographic Commission asks some key questions: "Do you have or expect human activities that adversely affect important natural areas of your marine areas, or incompatible human activities?" and "Do you need a vision of what your marine area could or should look like in another 10, 20 or 30 years?" For the Arctic, the answers are yes to both.

However, the purpose of such an Arctic plan would likely differ from plans in Central Europe and North America. In these areas, marine planning is used to manage a nearly overwhelming number of activities in an insufficient amount of space. In the Arctic, on the other hand, spatial planning could be used for preventive and precautionary purposes before the area is overwhelmed by marine activities and spatial conflicts become a major problem. ${ }^{108}$ Marine spatial planning in the Arctic should build on known procedural principles. The use of impact assessments from the outset of the planning process, in contrast to ad hoc, add-on assessments after final elaboration of a development proposal, could play a vital role. It is argued that, when better integration with planning is achieved, strategic and project impact assessment has demonstrated that it is not only capable of preventing harm, but can also contribute to better holistic solutions and thus represent a significant step forward in the evolution of an ecosystem approach in marine management. ${ }^{109}$

Even though Arctic marine ecosystems are geographically extensive, marine spatial plans for the Arctic could limit themselves to interactions that occur between existing and proposed activities, and focus on pressing national and transnational protection 
and planning needs in relation to e.g. transport routes, areas for pipelines and pertaining zones. Transnational challenges should be a particular priority.

The formal and legal aspects of marine spatial planning in the Arctic must be given due consideration in order to ensure that decisions regarding marine activities are made in compliance with marine spatial plans. At the same time, the marine spatial plans should be living instruments that are altered and amended as future uses of the Arctic space are proposed and new insight is brought to the table.

\section{NOTES}

1. See examples on research publications in the following references, the work done by UNESCO/ the Intergovernmental Oceanographic Commission promoting management procedures and policies on ecosystem based management through MSP, and the development in EU of the directive on Maritime Spatial Planning (MSP) (2014/89/EU).

2. Fanny Douvere, “The importance of marine spatial planning in advancing ecosystem-based sea use management", Marine Policy 32 (2008): 766.

3. Jens-Uwe Schröder-Hinrichs, Henrik Nilsson and Jonas Pålsson, "Sustainable Ocean Development in the Arctic: Making a Case for Marine Spatial Planning in Offshore Oil and Gas Exploration", Ocean Yearbook Online 27(1) (2013): 522.

4. The terms marine and maritime are used synonymously here, see also Helena Calado et al., "Marine spatial planning: lessons learned from the Portuguese debate", Marine Policy 34(6) (2010): 1341.

5. See Charles Ehler and Fanny Douvere, Marine Spatial Planning: a step-by-step approach toward ecosystem-based management, Intergovernmental Oceanographic Commission Manual and Guides No. 53, UNESCO, Paris, 2011: http://hdl.handle.net/11329/209.

6. http://msp.ioc-unesco.org/about/marine-spatial-planning/.

7. Generelly accepted as the five coastal states, see ErikJ. Molenaar et al., "Introduction to the Arctic", in Arctic marine governance. Opportunities for transatlantic cooperation, ed. Elizabeth Tedsen, Sandra Cavalieri, R. Andreas Kraemer (Springer, 2014), 4.

8. For the basic distinction between marine areas made by the United Nations Convention on the Law of the Sea, 1982, and that also exist in the marine Arctic, see Ibid., 5-6.

9. For the Norwegian Sea, both value creation and maintaining the high environmental value of the area are highlighted, see Report No. 37 to the Storting (2008-2009) Integrated Management of the Marine Environment of the Norwegian Sea sec 2.3 Objectives and purposes of the management plan, Geir Ottersen et al., "The Norwegian plan for integrated ecosystem-based management of the marine environment in the Norwegian Sea", Marine Policy 35 (2011): 390, and again upheld in the updated plan, Meld. St. 35 (2016 - 2017) Oppdatering av forvaltningsplanen for Norskehavet sec. 2.

10. Peter J.S. Jones, Louise Marie Lieberknecht and Wanfei Qiu, "Marine spatial planning in reality: Introduction to case studies and discussion of findings", Marine Policy 71 (2016): 256-264.

11. Ibid.

12. Douvere, The importance of marine spatial planning in advancing ecosystem-based sea use management, 766.

13. Sue Kidd and Geraint Ellis, "From the Land to Sea and Back Again? Using Terrestrial Planning to Understand the Process of Marine Spatial Planning”, fournal of Environmental Policy \& Planning 14 (2012): 49.

14. Report of the World Commission on Environment and Development: Our Common Future, 1987, chap. 10, I 2. Oceans management; "15. Looking to the next century, the Commission 
is convinced that sustainable development, if not survival itself, depends on significant advances in the management of the oceans. Considerable changes will be required in our institutions and policies and more resources will have to be committed to oceans management".

15. Calado et al., Marine spatial planning: lessons learned from the Portuguese debate, 1341.

16. Baselines are the normal lines for measuring the breadth of territorial waters, following the low-water line of the state, but, as in the case Norway, whose coastline is deeply indented, straight baselines joining appropriate points may be used, see The United Nations Convention on the Law of the Sea, 1982, sections 5 and 7.

17. EU Water Framework Directive, Directive 2000/60/EC establishing a framework for Community action in the field of water policy.

18. Sigrid Eskeland Schütz, "Renewable energy production in marine areas and coastal zone the Norwegian model", in Delivering Energy Law and Policy in the EU and US: A Reader, ed. Raphael J. Heffron and Gavin Little (Edinburgh: Edinburgh University Press, 2016).

19. The Norwegian Planning and Building Act (PBA), Act No 71 of 27 June 2008 section 1-2.

20. UNCLOS, preamble recital 4.

21. Frank Maes, "The international legal framework for marine spatial planning", Marine Policy 32 (2008): 799.

22. Jeff Ardron et al., "Marine spatial planning in the high seas", Marine Policy 32 (2008): 832.

23. Convention on Biological Diversity, 1992.

24. Convention for the Protection of the Marine Environment of the North-East Atlantic, 1992.

25. Directive 2008/56/EC establishing a framework for community action in the field of marine environmental policy.

26. For an overview, see Maes, The international legal framework for marine spatial planning, 797-810.

27. Gabčíkovo-Nagymaros (1997) ICJ Reports, para. 35.

28. Ibid., para. 112 .

29. Ibid., para. 140 .

30. Pulp Mills (2010) ICJ Reports, para. 204.

31. Ibid., para. 205.

32. International tribunal for the law of the sea, advisory opinion of 1 February 2011, Responsibilities and obligations of States sponsoring persons and entities with respect to activities in the Area, List of cases: No 17, para. 148.

33. http://www.beaufortseapartnership.ca/

34. Sabine Jessen, "A Review of Canada's Implementation of the Oceans Act since 1997-From Leader to Follower?”, Coastal Management 39 (2011): 24-25, with further references.

35. For further information on US Coastal and marine spatial planning, see https://cmsp.noaa. gov/.

36. https://www.regjeringen.no/en/topics/climate-and-environment/biodiversity/ innsiktsartikler-naturmangfold/forvaltningsplaner-for-havomrada/id2076485/

37. These processes for opening areas are regulated by law, see the Norwegian Act relating to petroleum activities, Act No 72 of 29 November 1996 and the Offshore Energy Act, Act No 6 of 21 April 2010.

38. Larry Crowder and Elliott Norse, "Essential ecological insights for marine ecosystem-based management and marine spatial planning", Marine policy 32 (2008): 773.

39. Recognised in the preparatory works to the SEA Directive, Directive 2001/42/EC of 27 June 2001 on the assessment of the effects of certain plans and programmes on the environment, see COM 96(511), 5.

40. Gunnar Sander, "International Legal Obligations for Environmental Impact Assessment and Strategic Environmental Assessment in the Arctic Ocean", The International fournal of Marine and Coastal Law 31 (2016): 91. 
41. Vito De Lucia, "Competing Narratives and Complex Genealogies: The Ecosystem Approach in International Environmental Law”, fournal of Environmental Law 27 (2015): 91.

42. Conference of the Parties (COP), COP 5 Decision V/6, B, Principle 7.

43. For an illustration of the importance of bearing in mind legal cultures when studying legal transplant of a regulatory tool, see Sanja Bogojevic, Emissions trading schemes: markets, states and law (Bloomsbury Publishing, 2013).

44. Sander, International Legal Obligations for Environmental Impact Assessment and Strategic Environmental Assessment in the Arctic Ocean, 95.

45. Ibid., 118.

46. The UNECE Convention on Access to Information, Public Participation in Decisionmaking and Access to Justice in Environmental Matters, 1998.

47. UNECE Convention on Environmental Impact Assessment in a Transboundary Context, 1991.

48. For an overview of international legal obligations for impact assessment in the Arctic Ocean, see Sander, International Legal Obligations for Environmental Impact Assessment and Strategic Environmental Assessment in the Arctic Ocean.

49. SEA Directive, Directive 2001/42/EC of 27 June 2001 on the assessment of the effects of certain plans and programmes on the environment and the EIA Directive 2011/92/EU of 13 December 2011 on the assessment of the effects of certain public and private projects on the environment. It should be noted that the European Union has no regulations on terrestrial land use planning or coastal zone planning. Even so, procedural requirements for environmental impact assessments under EU directives have also influenced land use planning, coastal planning and marine spatial planning in the EU member states.

50. Marc Pallemaerts, The Aarhus Convention at ten: interactions and tensions between conventional international law and EU environmental law (Groningen: Europa Law Publishing, 2011), 399-400, note 20.

51. Ibid., 282-283.

52. Pavel Bykov, "Comparison of Russian and Finnish Planning Systems and Land Use Laws", Thesis, Saimaa University of Applied Sciences (2012): 54.

53. The EU has not been granted 'observer status' in the Arctic Council, but was previously an ad hoc observer, see: http://www.arctic-council.org/index.php/en/about-us/arctic-council/ observers.

54. Art. $3(2)$.

55. Art. $13(1)$.

56. Art. $4(1)$.

57. Art. 6 (3).

58. Note that the directive only addresses plans and programmes prepared or adopted by an authority (at national, regional or local level) and required by legislative, regulatory or administrative provisions, cf. the Directive art. 2 (a).

59. EIA Directive art. 3.2 (a) has the same wording as the scope defined in art. 4(2) in the SEA Protocol under the Espoo convention.

60. European Parliament resolution of 20 January 2011 on a sustainable EU policy for the High North $(2009 / 2214$ (INI)), sec. 1.

61. See further details in Ellen Margrethe Basse, "En sammenligning af de retlige forhold vedrørende naturressourcer og miljø på Grønland og Svalbard", in Lov, liv og lere, Festskrift til Inge Lorange Backer, ed. Hans Chr. Bugge (Oslo: Universitetsforlaget, 2016).

62. Codified in Council Decision 2014/137/EU of 14 March 2014 on relations between the European Union, on the one hand, and Greenland and the Kingdom of Denmark, on the other.

63. Basse, En sammenligning af de retlige forhold vedrørende naturressourcer og miljø på Grønland og Svalbard, 32 . 
64. The European Economic Area, 1992.

65. See art. 29 and 31.

66. Basse, En sammenligning af de retlige forhold vedrørende naturressourcer og miljø på Grønland og Svalbard, 32.

67. The Norwegian Planning and Building Act, Act No 71 of 27 June 2008.

68. Municipal land use planning in contravention of laws, regulations, governmental guidelines and provisions or regional plans can give the county, a neighbouring municipality or affected national expert authorities a right to 'object' to the local plan, see PBA section 5-4. Unless the municipality takes the objections into account, the contested part of the plan shall be sent to the Ministry of Local Government and Modernisation for approval, see section 5-6.

69. See PBA sec. 12-1.

70. Sec. 11-3.

71. Sec. 11-11.

72. St.meld. nr. 12 (2001-2002) Rent og rikt hav, Report to the Storting (white paper), Protecting the Riches of the Sea.

73. St.meld. nr. 8 (2005-2006), Helhetlig forvaltning av det marine miljø $i$ Barentshavet og havomradene utenfor Lofoten (forvaltningsplan), Report to the Storting (white paper), Integrated Management of the Marine Environment of the Barents Sea and the Sea Areas off the Lofoten Islands.

74. Meld. St. 10 (2010-2011), Oppdatering av forvaltningsplanen for det marine miljø $i$ Barentshavet og havomradene utenfor Lofoten, Report to the Storting (white paper), First update of the Integrated Management Plan for the Marine Environment of the Barents Sea - Lofoten Area.

75. Charles N. Ehler, "Pan-Arctic Marine Spatial Planning: An idea whose time has come", in Arctic marine governance. Opportunities for transatlantic cooperation, ed. Elizabeth Tedsen, Sandra Cavalieri, R. Andreas Kraemer (Springer, 2014), 205, Erik Olsen et al., "Integration at the Round Table: Marine Spatial Planning in Multi-Stakeholder Settings", PLoS ONE 9 (2014): 3-4, and Erik Olsen et al., "How Integrated Ocean governance in the Barents Sea was created by a drive for increased oil production", Marine Policy 71 (2016): 294.

76. Schröder-Hinrichs, Nilsson and Pålsson, Sustainable Ocean Development in the Arctic: Making a Case for Marine Spatial Planning in Offshore Oil and Gas Exploration, 523 characterise this plan as a marine spatial plan, likewise Ehler, Pan-Arctic Marine Spatial Planning: An idea whose time has come, 200.

77. Act relating to the management of wild living marine resources 6 June 2008 No 37 .

78. Vassily A. Spiridonov et al., Atlas of marine and coastal biological diversity of the Russian Arctic (Moscow: WWF Russia, 2011), ISBN 9785990278622.

79. Bykov, Comparison of Russian and Finnish Planning Systems and Land Use Laws.

80. http://www.partiseapate.eu/

81. Spiridonov et al., Atlas of marine and coastal biological diversity of the Russian Arctic, 5.

82. Coutry Fishe, Russia, HELCOM, October 2016 at http://www.helcom.fi/action-areas/maritime-spatial-planning/country-fact-sheets/russia/, section 4.1.11.

83. http://www.partiseapate.eu/

84. John Richard Hansen, Oleg Korneev and Julia Tchernova, "Norwegian-Russian environmental cooperation in the Barents Sea. Toward development of a coordinated ecosystem based management", (2015): http:/www.npolar.no/no/kronikker/2015/0813-okosystem-barentshavet.no.html. In an ecosystem-based management perspective, national borders seem to be irrelevant. The large marine ecosystems of the Arctic, as defined in the work of the Arctic Council, are drawn irrespective of national borders. 
For instance, the Barents Sea is shown as a large marine ecosystem across the marine borders of Norway and Russia.

85. Ibid. There is strong joint Norwegian-Russian collaboration in the region. A work plan of the Russian Ministry of Natural Resources until 2018 include the development of a "Pilot project of integrated environmental management of the Arctic seas", (the Russian part of the Barents Sea), and is stated to include "development of the regulatory framework, Marine plan of the Barents Sea and carrying out necessary research and environmental monitoring", see Coutry Fishe, Russia, HELCOM, October 2016 at http://www.helcom.fi/action-areas/ maritime-spatial-planning/country-fact-sheets/russia/

86. Convention on the Protection of the Marine Environment of the Baltic Sea Area, HELCOM, 1974 and HELCOM, 1992.

87. HELCOM Baltic Sea Action Plan, adopted by a HELCOM Ministerial Meeting in 2007.

88. Hermanni Backer, "Transboundary maritime spatial planning: a Baltic Sea perspective", fournal of coastal conservation 15 (2011): 648.

89. HELCOM Baltic Sea Action Plan, adopted by a HELCOM Ministerial Meeting in 2007, 58.

90. http://www.helcom.fi/action-areas/maritime-spatial-planning/helcom-vasab-groups-on-msp/.

91. Grønlands Økonomi 2015, Økonomisk råd.

92. See also Basse, En sammenligning af de retlige forhold vedrørende naturressourcer og miljø på Grønland og Svalbard, 13 -14. See 'List of mineral and petroleum licences in Greenland', 1 February 2016 at https://www.govmin.gl/

93. http://nunaoil.gl/en

94. Basse, En sammenligning af de retlige forhold vedrørende naturressourcer og miljø på Grønland og Svalbard, 13.

95. Inatsisartutlov nr. 17 af 17 . november 2010 om planlægning og arealanvendelse, sections 17 and 18.

96. Fourth national report on the implementation of the Convention on biological diversity of Greenland, (undated), Chapter IIII.

97. Ibid.

98. Robert Siron, David VanderZwaag and Helen Fast, "Ecosystem-based Ocean Management in the Canadian Arctic", in Best Practices in Ecosystem-based Oceans Management in the Arctic, ed. Alf Håkon Hoel (Tromsø: Norwegian Polar Institute, 2009).

99. Greenland's oil and mineral strategy 2014-2018, Government of Greenland, February 2014, at http://nunaoil.gl/en.

100. https://allseas.com/project/statoil-polarled

101. https://www.scientificamerican.com/article/an-internet-cable-will-soon-cross-the-arcticcircle/

102. Ardron et al., Marine spatial planning in the high seas, 837.

103. Kamrul Hossain and Kathleen Morris. "Protecting Arctic Ocean Marine Biodiversity in the Area Beyond National Jurisdiction", in The Future of the Law of the Sea, ed. Gemma Andreone (Springer, 2017), 105-126.

104. https://oaarchive.arctic-council.org/handle/11374/417

105. Development of an international legally-binding instrument under the United Nations Convention on the Law of the Sea on the conservation and sustainable use of marine biological diversity in areas beyond national jurisdiction, document A/69/L.65, United Nations General Assembly, 11 May 2015. On an Arctic perspective on marine protected areas in international law see, Ingvild Ulrikke Jacobsen, Marine protected areas in international law. An Arctic perspective (Boston: Brill Nijhoff, 2016).

106. Schröder-Hinrichs, Nilsson and Pålsson, Sustainable Ocean Development in the Arctic: Making a Case for Marine Spatial Planning in Offshore Oil and Gas Exploration, 516. 


\section{S. E. Schütz}

107. Ibid., 528.

108. As recommended in Marine Spatial Planning: International Lessons for Canadian Development, Fisheries and Oceans Canada, Gulf region oceans management series 2011/01, 26.

109. Sander, International Legal Obligations for Environmental Impact Assessment and Strategic Environmental Assessment in the Arctic Ocean, 119. 